\title{
Moderating Variables On SME's Strategies And Competitiveness For International Trade: A Survey Of Horticultural Traders In Urban And Peri-Urban Areas In Kenya
}

Joel K. Tenai, Moi University, Kenya

Julius K. Bitok, Moi University, Kenya

Thomas K. Cheruiyot, Moi University, Kenya

Loice C. Maru, Moi University, Kenya

\begin{abstract}
Small and Medium sized Enterprises (SME) strategy and competitiveness in international trade in developing countries context have not been fully explored. This paper posits that SME's competitiveness as a result of its strategy is moderated by an array of internal and external factors. Accordingly, this paper examines key moderating variables on the SME's strategies as a construct that influence enterprise competitiveness. The objectives of the paper are three fold: to identify the moderating factors on SME strategies and competitiveness, to evaluate the level and extent of moderation of such variables and to evaluate the relationship between enterprise strategy and competitiveness. The hypotheses were developed and tested using data collected using survey of traders in the urban and peri-urban areas of Uasin Gishu District, Kenya. Systematic random sampling technique was used to pick 50 of the 200 traders in the market. Data was collected using self-administered structured questionnaire to the respondents. Factor analysis was used to extract latent factors and provide an understanding of structures and identify the moderating factors. Further, linear multiple regression analysis was performed on the extracted factors against sales volume as a measure of competitiveness. This was used in the assessment of various dimensions of the enterprise performance of SME'S. Ten factors with high eigen values of more than one were extracted. The regression model could not provide conclusive results on the effect of strategy on competitiveness, but could be indicative of the complexity of the underlying interactions.
\end{abstract}

Keywords: SME's internal factors, external factors, moderating factors on SME strategy-competitiveness.

\section{INTRODUCTION}

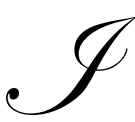

$\mathrm{t}$ is generally assumed that small firms, regardless of their geographical location engage in minimal export activities compared with large firms (K' Obonyo 2004). Some studies however have reported zero or negative correlation between firm size and export behavior (Calof 1993).

Traditionally, the concept of competitiveness has been adopted from economic theory and applied at the firm level (Yoon 2002). Competitiveness has also been described from an industrial enterprise perspective. Porter's competitive strategy is based on an analysis of a company's position within its industrial environment (Porter 1980:1986).

Mc Fridge (1995) gives competitiveness at three different levels of aggregation: the firm, the industry or groups of industries and the nation. A focus on firm-level competitiveness implies a limited role for government. A nation is as competitive as its firms. Whether a firm is competitive depends on how it is managed. At each level of 
aggregation, there are different measures, or indicators, of competitiveness. They vary in what they imply about the present and future economic success or well-being of a firm, industry or nation. Some concepts of competitiveness are applicable at one level of aggregation but not at another.

At the firm level, sales volume profitability, cost, productivity and market share are all indicators of competitiveness. Profitability may be a sufficient indicator of current competitiveness, although profitability is best measured over an extended period. Market share may also be a sufficient indicator of competitiveness if the firm is maximizing profits (that is, not sacrificing profits in the pursuit of market share for its own sake). Of course, a firm can be competitive in a market that is itself declining. In this case, competitiveness does not ensure future profitability.

According to ( $\mathrm{K}$ ' Obonyo 2004) small firms, like their large counterparts operate in dynamic and competitive markets. Success in such markets depends on a firms strategic positioning for competitiveness. According to Porter (1980), a firm's competitive strategy is a multi-dimensional concept. Hambrick (1993) and Millers, (1986) identified five dimensions of strategy to include: innovation differentiation, cost efficiency, asset parsimony, reactive and domain scope. K'Obonya (2004) further posits that small firms need to focus on keeping a coherent pattern in their strategy for better performance given intensified market competition and paucity of resources particularly in less developed countries. Adhikary (2001: 381) argues that competition is the heart of efficiency, which is a prelude to effectiveness, which in turn induces a firm to aspire for excellence in its performance.

Competitiveness could be cultivated by any firm irrespective of size. However, may be achieved through a clear strategy orientation and the outcome of strategy may be moderated and influenced by an array of factors within and outside the firm. Internally, firm's strategy may be moderated and influenced by firm size, organizational entrepreneurship (creativity and innovation orientation) top management attributes(such as self efficacy, tolerance for ambiguity, risk attitude), firm's resource base, planning horizon, longevity of the firm and ownership orientation (sole proprietorship, partnership or limited company). Externally, firm's strategy may be moderated and influenced by factors such as access to the market and external financial support, competition intensity and environmental hostility and dynamism.

Departing from earlier approaches to understanding of strategy-competiveness relationship, this paper attempted to establish and assess the extent to which moderating variables influence the strategy-competitiveness relationship in SMEs particularly for international trade.

\section{Horticulture Industry and SMEs Export Opportunities in Kenya}

Horticulture is one of the leading export industries in Kenya. It falls under the Ministry of Agriculture which has the mandate to co-ordinate the implementation of all relevant policies for sustainable development of the industry. The Government has put in place institutional structure to support the development of the industries.

The leading export horticultural crop in Kenya is cut-flower (53\%) while vegetables (38\%) and fruits (9\%) follow (HCDA Report, 2006). Growing and exporting of cut-flowers is undertaken mainly by large local and multinational firms. However, opportunities for export of vegetables and fruits exist for SMEs at farmer or trader levels.

\section{Research Problem}

The horticulture industry provides export business opportunities in Kenya. However, the annual report by Horticultural Development Authority of Kenya (2006) indicates a stagnating trend in the volume of exports particularly of fruits and vegetable products. Some of the reasons that traditionally have explained this trend in developing countries perspective may include harsh climatic conditions in the face of global warming, exchange rate risk, poor infrastructure, inadequate access to finances and inadequate market information among others. 
Despite environmental concerns for firms to enter and gain competitiveness in international business, irrespective of size, they require a clear strategic orientation. However, such a strategy may be moderated and influenced by the aforementioned factors to some extent and determine the firm's ability to mitigate the limiting factors to competitive. Little is known so far about this and hence this paper attempts to establish and assess the extent to which moderating variables influence the strategy-competitiveness relationship in SMEs particularly for international trade.

\section{Objectives of the study}

1. To identify the moderating factors on SME strategies and competitiveness

2. To evaluate the level and extent of moderation of such variables

3. To evaluate the relationship between firm strategy and competitiveness

\section{Internal Environment and the Strategy-Competitiveness Relationship}

The enterprise competitiveness is easily identifiable at firm level. Metcalf, Ramlogan and Uyarra (2003) cited in UNCTAD (2004) maintain that competitiveness is embodied in the characteristics of the firm through: the current efficiency and effectiveness of the use of resources; the willingness and the ability to relate profitability to growth of capacity through continued investment; and the ability to innovate in technology and organization and thus improve efficiency and effectiveness of production. Competitive advantages, which must be measured in relation to rivals in markets, are determined by how efficient and effective the prevailing markets for products, labor and capital are.

Firm's entrepreneurship capacity refers to the introduction of new productive combinations and innovations acting as driving forces, which continually create new competitive advantages and opportunities for profit and growth. Organizational entrepreneurship or entrepreneurial firm behavior involves actions to new entry or direction to novelty (Covin and Slevin, 1991; Lumpkin and Dess, 1996; Zahra, 1993). It captures organizational processes, methods, and styles for implementing entrepreneurship as described by three sub-dimensions important for longterm competitiveness. Innovativeness, the first dimension, is the degree a firm creates and introduces new products or services (Zahra, 1993). Risk taking, the second dimension, addresses large and risky resource commitments that a firm undertakes and that have a chance of failure (Miller and Friesen, 1982). Finally, proactive ness is the extent to which a firm seizes opportunities in the marketplace (Lumpkin and Dess, 1996; Zahra and Covin, 1995).

CEO personality is also important for competitive outcomes in strategic SME networks. Two lower abstraction constructs have been identified in the literature: CEO self-efficacy and tolerance for ambiguity. CEO self-efficacy concerns beliefs in "capabilities to mobilize the motivation, cognitive resources, and courses of action needed to exercise control over events" (Wood and Bandura, 1989: 364). CEO tolerance for ambiguity is the extent to which CEOs feel threatened by ambiguous situations, which affects their confidence when undertaking actions. Proactive trait-alike factors from the CEO can make the firm overcome impediments, such as fear of opportunistic partners that may hinder a firm from cooperating in the network. Moreover, it is likely that CEO personality will direct attention to engage in networking or participate in cooperate projects in strategic SME networks, since they tend to be uncertain about outcomes (Biggiero, 2001; Sherer, 2003).

Cheruiyot et al (2006) argues that entrepreneurs play a key role in determining the vision of the enterprise and that SME owner may be categorized as Aggressive, Strategic, Adaptive and Imitative (ASAI), which is indicative of their divergent strategic orientations.

Firm size may be highly argued to be indicative of the strategic positioning and the resultant competitiveness. Firm size, proposed as an important characteristic to gain competitiveness effects can be regarded as a proxy for resources where larger firms usually possess more product lines and higher production capacity together with organizational resources and slack (Alvarez and Barney, 2001). Firm size is likely to influence market participation and competitive strategies by the firm. Larger firms may be able to compete on the basis of brand image, price amongst other factors. Although smaller firms may be more flexible (Chen and Hambrick, 1995), it can be argued that larger firms have better prerequisites for strategic behavior compared to their smaller counterparts. In 
fact, based on the premises just mentioned, larger firms may be better equipped to engage in export business.

Similarly the firm longevity could reflect the firm product lifecycle and hence strategic behavior. Longevity gives an indication of a firm's experience in export business operations and from learning from more advanced business partners. The rise of globally integrated value chains, driven by multi-national corporations, is creating "first mover" advantages for firms that insert themselves early into subcontracting relationships. Over time, such firms improve their competitiveness by accessing new technologies, managerial practices, and technical and marketing skills.

Foreign buyers sometimes set higher standards for export goods. In such a situation a SME may remain competitive if it can access up-to-date market information and ensuring that production processes and product designs are more flexible and closely adapted to changing markets. Foreign buyers often demand higher technical, environmental and labour standards. Changing consumer demand (associated with rising incomes and changing tastes that come with greater prosperity) for more sophisticated, customized and environmentally-friendly products places new demands on firms (International Trade Forum, 2007). This paper therefore suggests that:

$\mathbf{H}_{1 \mathbf{a}}$ : Internal Factors will moderate the relationship between SMEs strategy and Competitiveness.

\section{External Environment and the Strategy-Competitiveness Relationship}

Meyer-Stamer (1995) concurs with the view that competitiveness is created at the firm level, but that it is partly derived from a systemic context, emerging from complex patterns of interactions between government, enterprises and other actors, and will therefore exhibit different forms in each society. SME development strategies will thus necessarily be country and context specific. Each country will have its own challenges, opportunities and priorities for change, and resources available for implementation will vary by country.

Close and active partnership, a coherent competitiveness strategy, tailor-made to national circumstances, has a major influence on the creation of business competitiveness. A close and active business-government partnership is the linchpin of a well-managed competitiveness strategy. Traditionally, business focuses on increasing profits, while government formulates and implements strategy. However, success in the new global context implies a change in this traditional division of labour. Accessing new resources and markets while mitigating the risks of intensive competition calls for a new kind of relationship between business and government. In this context, government plays a leading but not a dominant role in managing competitiveness strategy. The role of the business sector is different.

A firm benefits from externalities derived from the existence of technological capability and export competitiveness at the national level. Lall (2000: 21) stresses that "national technological capability is more than a sum of capabilities of individual firms in a country. It is an innovation system, which includes the externalities and synergy generated by the learning process, ways of doing business, and the knowledge and skills residing in related institutions".

To respond effectively to the demanding global environment, firms need to develop a range of export capabilities in the areas of technology, marketing, management, human resources and finance, and continuously upgrade them over time. However, building business competitiveness, particularly for export markets, also has to involve both governments and trade support institutions in a major way. They need to support competitiveness with a coherent strategy. Translating this strategy into success depends on a close and active partnership between business and government. Systematically building business competitiveness is linked to export success in developing countries. The efficiency with which firms or sectors improve their export capabilities, including through the use of ICTs, can change the basis for comparative advantage of the whole country. This paper thus proposes that:

$\mathbf{H}_{\mathbf{1 b}}$ : External Factors will moderate the relationship between SMEs strategy and Competitiveness. 


\section{Relationship between Firm's Strategy and Competitiveness}

Competitiveness of SME's internationally could be better understood by attempts to examine the relationship between strategy as an antecedent for enterprise competitiveness. This paper therefore proposes that:

$\mathbf{H}_{2}$ : There is a positive relationship among strategy-competitiveness constructs.

\section{METHODOLOGY}

The study was an exploratory survey of traders in the Urban and Peri-Urban areas of Uasin-Gishu District of Kenya. The target respondents were traders registered by the Horticultural crops Development Authority (HCDA), to plying their trade in the Eldoret Municipal Market in the month of September 2007. The sample frame consisted of 200 traders meeting the above specified requirements. Systematic random sampling technique was used to pick 50 of the 200 traders in the market. Data was collected using a personally administered structured questionnaire to the respondents. Various items in the questionnaire contained Likert type questions to capture attitudes and perceptions. Factor analysis was used to understand structures and identify the moderating factors. This was complemented by linear multiple regression that have been used in the assessment of various dimensions of the enterprise performance of SME'S.

\section{Measures}

Firm size was measured using the number of employees and categorized as micro, small and medium enterprises.

Corporate entrepreneurship: A five-point Likert scale developed by Zahra and Covin (1995) (based on Miller and Friesen, 1982) was used to measure the degree of corporate entrepreneurship. This measure includes risk taking, proactiveness, and innovativeness.

Firm competitiveness was measured using sales values. Four self-reported measures were used as an index to measure firm performance, consisting of sales growth, customer satisfaction, productivity, and Profitability.

CEO attribute was captured by perceived self efficacy, tolerance for ambiguity, risk attitude of the business owner/manager.

Planning horizon: The decision maker's holding period in the business. This could be short term or long term.

Longevity: of the SME; the period from startup to the present. The maturity of the firm may influence the strategies.

\section{DATA ANALYSIS AND DISCUSSIONS OF FINDINGS}

The response rate was high (100\%) because the instrument was personally administered to the respondents. Data was verified to delete missing data and outliers. Reliability test using Cronbach alpha was performed on the Likert type responses and was found to range from modest $(0.469)$ to excellent $(0.724)$. However one $(0.263)$ was found to be poor as shown on Table 1.

Table 1: Reliability Tests

\begin{tabular}{|c|l|c|}
\hline & \multicolumn{1}{|c|}{ Construct } & Cronbach $\boldsymbol{\alpha}$ \\
\hline 1 & Corporate entrepreneurship & 0.70 \\
\hline 2 & CEO attributes & 0.50 \\
\hline 3 & Environmental Hostility and dynamism & 0.26 \\
\hline 4 & SME export strategies & 0.53 \\
\hline
\end{tabular}

Source: Survey Data, (2008) 


\section{The Moderating Factors on SME Strategies and Competitiveness}

Principal factors extraction with Varimax rotation was performed through SPSS factor on

Items from a sample of 50 traders. Principal component factor analysis was performed on the 28 various itemized responses from the sample population. All the communalities were less than one proving to be satisfactory. Ten components (factors) were extracted representing the determiners and associated variables on attributes, perceptions and attitudes of owners of SME's on environmental hostility and dynamism, export strategies, among other variables. Ten components with initial eigenvalues of more than one was extracted using principal component analysis (PCA). These were found to explain up to $73.69 \%$ of the variance. This is shown in table 2 below. The first three factors account for a total of $35.724 \%$ of the variance.

Table 2: Total Variance Explained

\begin{tabular}{|c|c|c|c|c|c|c|c|c|c|}
\hline \multirow{2}{*}{ Component } & \multicolumn{4}{|c|}{ Initial Eigenvalues } & \multicolumn{2}{c|}{$\begin{array}{c}\text { Extraction Sums of Squared } \\
\text { Loadings }\end{array}$} & \multicolumn{3}{|c|}{$\begin{array}{c}\text { Rotation Sums of Squared } \\
\text { Loadings }\end{array}$} \\
\hline & Total & $\begin{array}{c}\text { \% of } \\
\text { Variance }\end{array}$ & $\begin{array}{c}\text { Cumulative } \\
\text { \% }\end{array}$ & Total & $\begin{array}{c}\text { \% of } \\
\text { Variance }\end{array}$ & $\begin{array}{c}\text { Cumulative } \\
\text { \% }\end{array}$ & Total & $\begin{array}{c}\text { \% of } \\
\text { Variance }\end{array}$ & $\begin{array}{c}\text { Cumulative } \\
\text { \% }\end{array}$ \\
\hline 1 & 3.91 & 13.96 & 13.96 & 3.91 & 13.96 & 13.96 & 3.12 & 11.14 & 11.14 \\
\hline 2 & 3.18 & 11.34 & 25.29 & 3.18 & 11.34 & 25.29 & 2.51 & 8.95 & 20.09 \\
\hline 3 & 2.92 & 10.43 & 35.72 & 2.92 & 10.43 & 35.72 & 2.24 & 7.99 & 28.07 \\
\hline 4 & 2.37 & 8.46 & 44.18 & 2.37 & 8.46 & 44.18 & 2.22 & 7.93 & 36.00 \\
\hline 5 & 1.69 & 6.04 & 50.22 & 1.69 & 6.04 & 50.22 & 2.01 & 7.18 & 43.18 \\
\hline 6 & 1.51 & 5.40 & 55.63 & 1.51 & 5.40 & 55.63 & 1.94 & 6.91 & 50.09 \\
\hline 7 & 1.44 & 5.14 & 60.76 & 1.44 & 5.14 & 60.76 & 1.80 & 6.44 & 56.53 \\
\hline 8 & 1.40 & 5.01 & 65.78 & 1.40 & 5.01 & 65.78 & 1.76 & 6.29 & 62.82 \\
\hline 9 & 1.13 & 4.04 & 69.82 & 1.13 & 4.04 & 69.82 & 1.56 & 5.58 & 68.40 \\
\hline 10 & 1.08 & 3.87 & 73.69 & 1.08 & 3.87 & 73.69 & 1.48 & 5.29 & 73.69 \\
\hline
\end{tabular}

Extraction Method: Principal Component Analysis.

\section{Determiners and Variables of Component Factors}

On interpretation, the researchers tried to understand the latent dimensions (factors) that unify the group of variables loading it. Based on the rule of thumb only factor loadings of 0.32 and above were interpreted (Kline 2005). The greater the loading the more the variable is a pure measure of the latent factor. The size of the loadings is influenced by the homogeneity of scores of that sample. If homogeneity is suspected, interpretation of lower loadings is warranted. Each of the ten components (factors) extracted were loaded with both external and internal moderating variable and could predict the influence it may have on a firms strategy. Based on the description of the various variables loading each factor has been named based on the likely resulting nature of firm and strategy. The ten components are summarized as shown in Table 3:

Factor 1 - moderately Strategic/Conservative: This factor is loaded by 8 moderating variables both internal and external. Four of the variables were external while four were internal. The heavily loading internal variables are non-assertiveness of business owners (0.77), self confidence (-0.59), internal locus of control (0.38), while the highest loading among the external variables is severe competition on quality (0.76), cooperation with others (-0.66), quality assurance, external network(-0.48) Such a firm is deemed to be moderately strategic and conservative.

Factor 2 -Efficient/Product Differentiation: Majority of the moderating variables loading on this factor are internal with the highest being the firm's quality assurance (0.53). Other variables that load significantly on this factor include ability to access market, new product development (0.83), predictability (0.80) among others. This finding infers that there are strong positive CEO's attributes and entrepreneurial attributes existing in the firm. This suggests when a firm's internal variables are strong; they moderate a strategy, while the external factors may not have a strong influence on a strategy. 
Factor 3 - Realistic/Static: This factor is loaded by a mix of both the external and internal moderating variables. Almost an equal loading of the factor from both sides of the environments seem to balance the operating situation to a point where the firms resigns to it and hence realistic/static nature. The following variables load on the Factor; Org learning (0.85), Product choice (0.75), Export inv(0.59) and lack of tolerance( 0.33$)$.

These findings suggest that the nature of the business environment (status quo) dictates the way the firm is operated. Hence the prevailing strategy may be influenced positively if the moderating factors from both sides positively moderate it.

Factor 4 - Reactive: Four internal moderating variables load on this factor. These findings suggest that since the external factors place more strain on the strategy than the internal one, the firm is likely to be reactive rather than proactive to market conditions. The strategy is unlikely to be strong owing to the weakness of the firm internally and it attempts to capture opportunities and satisfy then in a dynamic and uncertain market. Credit access $(0.83)$ Forecasting ability low (0.75) Severe price competition (0.47) and learning ability $(0.41)$

Factor 5 - Realistic/Product Innovation: Five variables have higher loadings on this factor. These are: severe entry barriers (0.77), access to support (0.69), price competition (0.35) organization learning (0.34) and cooperative (0.34). This factor has a higher loading of external moderating variables. This indicates that the firm is likely to be influenced by external barriers to trade, could be concerned about access to external financial resources and price competition. The possibility of cooperative strategies could be adopted by such a firm to mitigate these problems.

Factor 6 - Adaptive/Traditional: Moderating variable loading on this factor are more from the external than internal environments. The variables loading on the factor are: external locus of control (0.83), dynamic market reaction (0.52), market access (0.47), willing to cooperative (0.38) and product innovation (0.40). A firm in such a situation is likely to have an adaptive strategy and may remain traditional because the operating environment places strong strain on it.

Factor 7 - Aggressive/Static: Two external moderating variables load on this factors with one internal moderating variable. These are; uncertain market (0.92), dynamic market reaction (0.47) and self efficacy low (0.32).

Factor 8 - Internal locus of control and innovator; The moderating variables loading on this factor are both internal and external. Product innovation (0.65), price competition (0.60), internal locus of control (0.58) and severe price competition (-0.36). The likely strategy is innovative and externally influenced.

Factor 9 - Self-Efficacy/Brand strategy; This factor has a significant loading of two internal moderating variables. These are; Brand strategy (0.77) and self efficacy (0.72). The influence on the strategy is likely to be positive as the internal variables may favor strategy.

Factor 10 - Non-Strategic learning organization: This factor has significant loading of moderating variables on two variables both internal variables. These are; Non strategic (0.87) and learning ability (0.67). Such a firm is unlikely to have a strategy that can influence competitiveness.

\section{Relationship between the Moderating Factors on Strategy Competitiveness}

In order to improve interpretability and utility of the results, Varimax rotation with Kaiser Normalization was done and the rotation converged in 16 iterations. Two variables had the largest loading on each factor identified earlier were selected from rotated component matrix (see appendix 1). A total of 20 variables were identified for this purpose. Sales volume was used as a proxy for competitiveness. Using linear regression, the selected variables were regressed against it to predict firm's competitiveness.

Results of the analysis appended showed lack of significance in the variables' ability to positively predict sales volume hence potential competitiveness of a firm. However competition on quality (0.36) and access to credit $(0.29)$ had a loading on factor 1 and factor 4 . Two other variables: severe entry barriers (-0.378) and nonassertiveness $(-0.225)$ loaded on factor 5 and factor 1 . This model has moderate predictive power of $R^{2}=0.404$ as 
shown appendix 1 . However, being an exploratory study, the results may be useful for predicting strategycompetitiveness relationship in SMEs.

Table 3: Principal Component Matrix for Moderating Variables for SMEs Strategies and Competitiveness for International Trade

\begin{tabular}{|c|c|c|c|c|c|c|c|c|c|c|}
\hline & 1 & 2 & 3 & & 5 & 6 & 7 & 8 & 8 & 10 \\
\hline & $\begin{array}{c}\text { Conservative/ } \\
\text { static }\end{array}$ & $\begin{array}{c}\text { Self } \\
\text { efficacy/pro } \\
\text { differentiation }\end{array}$ & $\begin{array}{l}\text { Realistic/ } \\
\text { static }\end{array}$ & $\begin{array}{l}\text { Tolerance } \\
\text { for } \\
\text { ambiquity } \\
\text { /reactive }\end{array}$ & $\begin{array}{l}\text { Realistic } \\
\text { /Product } \\
\text { innovation }\end{array}$ & $\begin{array}{l}\text { Adaptive/ } \\
\text { traditional }\end{array}$ & $\begin{array}{c}\text { Aggressive } \\
\text { /non } \\
\text { strategic }\end{array}$ & $\begin{array}{c}\text { Brand } \\
\text { dev/static }\end{array}$ & $\begin{array}{c}\text { High } \\
\text { External } \\
\text { locus of } \\
\text { control } \\
\text { /Learning } \\
\text { org }\end{array}$ & $\begin{array}{l}\text { Strategic } \\
\text { external }\end{array}$ \\
\hline $\begin{array}{l}\text { Non- } \\
\text { Assertiveness }\end{array}$ & .77 & .02 & -.01 & -.00 & -.03 & -.01 & .10 & .13 & .08 & .00 \\
\hline $\begin{array}{l}\text { Severe } \\
\text { comquality }\end{array}$ & .76 & -.01 & .02 & -.27 & -.03 & -.15 & .08 & -.24 & -.31 & -.14 \\
\hline Cooperative & -.66 & .20 & .01 & -.22 & -.34 & .38 & .06 & -.03 & .12 & .02 \\
\hline $\begin{array}{l}\text { Self } \\
\text { confidendence }\end{array}$ & -.59 & .33 & .14 & .33 & -.25 & -.02 & .17 & .18 & .00 & -.06 \\
\hline Ext Network & -.48 & .46 & -.22 & -.21 & .19 & -.07 & -.20 & .20 & -.23 & .14 \\
\hline New pro dev & -.17 & .83 & -.06 & -.18 & -.09 & -.15 & .22 & -.05 & .06 & .07 \\
\hline Predictability & -.02 & .80 & .04 & .04 & -.04 & -.05 & -.31 & .18 & -.05 & -.03 \\
\hline Quality ass & .44 & .53 & .12 & .05 & -.09 & .25 & -.04 & .16 & -.14 & .11 \\
\hline $\begin{array}{l}\text { Market } \\
\text { Access }\end{array}$ & -.20 & .49 & .23 & -.09 & .24 & .47 & .14 & -.06 & .11 & -.18 \\
\hline Org learning & .07 & .09 & .85 & -.01 & .34 & .04 & -.23 & -.01 & -.05 & .03 \\
\hline $\begin{array}{l}\text { Product } \\
\text { choice }\end{array}$ & -.18 & -.19 & .75 & -.26 & -.15 & .03 & .15 & .19 & -.09 & .02 \\
\hline Export inv & .18 & .20 & .59 & -.01 & .20 & .08 & -.26 & -.15 & .31 & .02 \\
\hline Credit access & .04 & -.08 & -.15 & .83 & .28 & -.04 & -.04 & .20 & -.03 & .04 \\
\hline $\begin{array}{l}\text { Forecastability } \\
\text { low }\end{array}$ & .27 & .10 & .20 & -.75 & .21 & .28 & .04 & .07 & -.04 & .01 \\
\hline $\begin{array}{l}\text { Severe } \\
\text { pricecomp }\end{array}$ & .42 & -.04 & .17 & .47 & -.01 & -.34 & .12 & -.36 & .05 & .28 \\
\hline $\begin{array}{l}\text { Severe entry } \\
\text { barriers }\end{array}$ & .19 & -.07 & .06 & .20 & .77 & -.07 & .02 & .14 & -.13 & -.04 \\
\hline $\begin{array}{l}\text { Access } \\
\text { extfinsuport }\end{array}$ & -.09 & .00 & .18 & -.11 & .69 & .04 & -.10 & .01 & .12 & .16 \\
\hline $\begin{array}{l}\text { Ext locus of } \\
\text { control low }\end{array}$ & -.05 & -.10 & .07 & -.09 & -.05 & .83 & -.03 & -.02 & -.04 & -.06 \\
\hline $\begin{array}{l}\text { Dynamic } \\
\text { market } \\
\text { reaction }\end{array}$ & .18 & -.02 & .05 & .25 & .01 & -.52 & .47 & .26 & .11 & -.14 \\
\hline $\begin{array}{l}\text { Uncertain } \\
\text { Market }\end{array}$ & .04 & -.01 & -.14 & -.09 & -.07 & .02 & .92 & -.06 & -.02 & -.04 \\
\hline Lack tolerance & -.03 & .16 & .33 & -.15 & .27 & .28 & -.35 & .20 & -.03 & .03 \\
\hline Prod innovate & -.12 & .22 & .08 & .05 & .03 & -.40 & -.03 & .65 & -.21 & .20 \\
\hline Price comp & -.13 & -.07 & .25 & .07 & .35 & .03 & .04 & .60 & .19 & .01 \\
\hline $\begin{array}{l}\text { Internal locus } \\
\text { of control }\end{array}$ & .38 & .28 & -.24 & .10 & -.06 & .06 & -.11 & .58 & .06 & -.05 \\
\hline Brand strategy & -.26 & .05 & .16 & .07 & -.21 & .04 & -.23 & .06 & .77 & -.04 \\
\hline $\begin{array}{l}\text { Self efficacy } \\
\text { low }\end{array}$ & .14 & -.12 & -.16 & -.08 & .23 & -.12 & .32 & -.01 & .72 & .07 \\
\hline Non strategic & -.03 & .01 & -.04 & -.12 & .21 & -.14 & -.12 & -.07 & .07 & .87 \\
\hline $\begin{array}{l}\text { Learning } \\
\text { ability }\end{array}$ & -.05 & .06 & .14 & .41 & -.11 & .10 & .06 & .24 & -.08 & .67 \\
\hline
\end{tabular}

Source: Research Data: Extraction Method: Principal Component Analysis. Rotation Method: Varimax with Kaiser Normalization.A Rotation converged in 16 iterations. 


\section{CONCLUSION}

This paper concludes based on its guiding objectives. Firstly, that several internal and external factors potentially exist that can moderate SMEs strategies and/or competitiveness. However, this study identified a mix of both internal and external variables that moderate SME strategies and/or competitiveness in the horticultural industry in Kenya.

Secondly, the study concludes that there are other variables that are yet to be identified that could positively predict sales volume hence competitiveness of a firm.

\section{RECOMMENDATIONS}

Based on the findings of this study, the following recommendations are proposed:

(i) It is necessary to enhance the internal and external factors/variables that influence SME strategycompetitiveness positively.

(ii) The internal attributes influencing SME strategy-competitiveness negatively should be influenced through training in relevant support areas, providing infrastructural support and the necessary resources as required by the firms.

(iii) A stronger partnership should be nurtured between the SMEs (private sector) and government to enhance competitiveness in international trade.

(iv) Best practices adopted by successful private firms/corporation should diffuse to SMEs through relevant learning systems.

\section{AUTHOR INFORMATION}

Joel Kipngetich Tenai, B. Com., M. Com. is a lecturer in the School of Business and Economics, Department of Accounting and Finance, Moi University. He is also the Head of the Department of Accounting and Finance and teaches courses in accounting, finance, company law, and quantitative techniques in business. He has taught for nine years. He is also a doctoral student in Business Management (Finance Option) in Moi University and is in the dissertation phase of the program.

Julius Kibet Bitok, B. Ed.(Maths), M.B.A.(Finance) is a lecturer in the School of Business and Economics, Department of Accounting and Finance, Moi University. He teaches courses in finance and quantitative techniques in business. He has taught for nine years. He is also a doctoral student in Business Management (Finance Option)in Moi University and is in the dissertation phase of the program.

Thomas Kimeli Cheruiyot, BBA., M. Com. is a lecturer in the School of Business and Economics, Department of Marketing and Management Science, Moi University. He teaches management science and quantitative techniques in business. He has taught for eleven years. He is also a doctoral student in Business Management( Strategic Management Option) in Moi University and is in the dissertation phase of the program.

Loice Chepngetich Maru, BBM., M. Phil(ENT) is a lecturer in the School of Business and Economics, Department of Marketing and Management Science, Moi University. She teaches courses in Small and Micro enterprise Development. She has taught for five years. She is also a doctoral student in Business Management( Strategic Management Option) in Moi University and is in the dissertation phase of the program.

\section{REFERENCES}

1. Alvarez, S.A. and Barney, J.B. (2001), "How can entrepreneurial Firms really benefit from Alliances with Large Firms?" Academy of Management Executive, Vol. 15, pp. 139-48.

2. Biggero, L. (2001). Self-organizing processes in building entrepreneurial networks: a theoretical and empirical investigation, Human Systems Management, Vol. 20, pp. 209-222.

3. Chen, M. and Hambrick, D.C. (1995), "Speed, stealth and selective attack: how small Firms differ from large Firms in competitive behaviour", Academy of Management Journal, Vol. 38, pp. 453-82. 
4. Cheruiyot T.K., Maru, L.C., Komen J., and Korir, M.K. 2006. Managerial Profiles of Women

Entrepreneurs in the Kerio Valley Basin of Kenya. African Journal of Business and Economics. Vol. 1 No.

1. Blue Sun. Nairobi, Kenya

5. Covin, J. G. and Slevin, D. P. (1991). A conceptual model of entrepreneurship as firm behavior.

Entrepreneurship: Theory and Practice, Vol. 16, pp. 7-25.

6. HCDA Copyright 2003 - 2007 Powered By Metrocomia East Africa (K) Ltd

7. Lumpkin, G. T. and Dess, G. G. (1996). Clarifying the entrepreneurial orientation construct and linking it to performance. Academy of Management Review, Vol. 21, pp. 135-172.

8. K'Obonyo, P. (2004) Strategic Orientation and Export Behaviour of Small Enterprises: a Conceptual Synthesis in Entrepreneurship Research and Development in Africa: Achievement,Challenges and Future Prospects. Erasmus S. Kaijage and Lufumbi J. Mwaipopo Eds. Mkuki na Nyota Publishers Ld. Dar es Salaam, Tanzania

9. Miller, D. and Friesen, P. (1982). Innovation in conservative and entrepreneurial firms: Two models of strategic momentum, Strategic Management Journal, Vol. 3, pp. 1-25.

10. Sherer, S. (2003). Critical Success Factors for Manufacturing Networks as Perceived by Network Coordinators. Journal of Small Business Management, Vol. 41, pp. 325-345.

11. Wood, R. and Bandura, A. (1989). Social Cognitive Theory of Organizational Management. Academy of Management Review, Vol. 14, pp. 361-384.

12. Zahra, S. A. (1993), A conceptual model of entrepreneurship as firm behavior: a critique and extension. Entrepreneurship: Theory \& Practice, Vol. 17, pp. 5-21.

13. Zahra, S. A., Nielsen, A. P. and Bogner, W. C. (1999). Corporate entrepreneurship, Knowledge and Competence Development. Entrepreneurship: Theory \& Practice, Vol. 23, pp. 169-189.

\begin{tabular}{|c|c|c|c|c|c|c|c|}
\hline \multicolumn{8}{|c|}{$\begin{array}{l}\text { APPENDIX I } \\
\text { Coefficients }\end{array}$} \\
\hline \multirow[t]{2}{*}{ Model } & \multicolumn{2}{|c|}{$\begin{array}{c}\text { Unstandardized } \\
\text { Coefficients }\end{array}$} & \multirow{2}{*}{$\begin{array}{c}\begin{array}{c}\text { Standardized } \\
\text { Coefficients }\end{array} \\
\text { Beta }\end{array}$} & \multirow[b]{2}{*}{$\mathbf{t}$} & \multirow[b]{2}{*}{ Sig. } & \multicolumn{2}{|c|}{$\begin{array}{l}\text { 95\% Confidence Interval } \\
\text { for B }\end{array}$} \\
\hline & B & Std. Error & & & & $\begin{array}{l}\text { Lower } \\
\text { Bound }\end{array}$ & $\begin{array}{l}\text { Upper } \\
\text { Bound }\end{array}$ \\
\hline (Constant) & 1326.054 & 452.044 & & 2.933 & .007 & 400.085 & 2252.023 \\
\hline $\begin{array}{l}\text { Severe com on } \\
\text { quality }\end{array}$ & 26.641 & 19.446 & .366 & 1.370 & .182 & -13.192 & 66.475 \\
\hline New Product. Devt & 7.042 & 44.850 & .041 & .157 & .876 & -84.829 & 98.913 \\
\hline Learning Ability & -31.730 & 42.803 & -.137 & -.741 & .465 & -119.409 & 55.949 \\
\hline Non-Strategic & -63.638 & 50.605 & -.245 & -1.258 & .219 & -167.296 & 40.021 \\
\hline Predictability & -12.416 & 55.584 & -.059 & -.223 & .825 & -126.274 & 101.442 \\
\hline Brand Strategy & 1.317 & 22.625 & .011 & .058 & .954 & -45.028 & 47.663 \\
\hline Rigid Personality & -30.249 & 52.799 & -.106 & -.573 & .571 & -138.402 & 77.904 \\
\hline Product Innovation & -5.953 & 67.637 & -.019 & -.088 & .930 & -144.500 & 132.595 \\
\hline Price Competition & 16.062 & 18.889 & .165 & .850 & .402 & -22.630 & 54.754 \\
\hline Access to finance & 13.969 & 25.263 & .110 & .553 & .585 & -37.780 & 65.719 \\
\hline Severe Entry Barriers & -60.396 & 33.009 & -.378 & -1.830 & .078 & -128.012 & 7.220 \\
\hline Non-assertiveness & -30.465 & 31.264 & -.225 & -.974 & .338 & -94.506 & 33.577 \\
\hline Uncertain Market & -28.630 & 32.247 & -.196 & -.888 & .382 & -94.685 & 37.425 \\
\hline $\begin{array}{l}\text { Dynamic Market } \\
\text { reactions }\end{array}$ & -15.831 & 36.829 & -.106 & -.430 & .671 & -91.271 & 59.609 \\
\hline $\begin{array}{l}\text { Low Ext. Locus of } \\
\text { control }\end{array}$ & -16.863 & 18.426 & -.177 & -.915 & .368 & -54.606 & 20.880 \\
\hline Credit Access & 29.023 & 27.446 & .290 & 1.057 & .299 & -27.197 & 85.243 \\
\hline Forecastability is low & 11.322 & 19.970 & .139 & .567 & .575 & -29.584 & 52.229 \\
\hline Lack of Tolerance & -30.371 & 27.056 & -.231 & -1.123 & .271 & -85.792 & 25.051 \\
\hline Product Choice & 31.033 & 48.788 & .153 & .636 & .530 & -68.905 & 130.970 \\
\hline $\begin{array}{l}\text { Organizational } \\
\text { learning }\end{array}$ & -26.214 & 37.214 & -.191 & -.704 & .487 & -102.443 & 50.015 \\
\hline
\end{tabular}

a Dependent Variable: Sales Volume $\mathrm{R}^{2}=0.404$ 